\title{
Promoting Comprehension Skills among At-Risk First Graders: The Role of Motivation in One-to-One Tutoring Environment
}

\author{
Baha Makhoul1,2,3, Elite Olshtain ${ }^{2}$, Raphiq Ibrahim ${ }^{4}$ \\ ${ }^{1}$ Oranim Academic College of Education, Tivon, Israel \\ ${ }^{2}$ The NCJW Research Institute for Innovation in Education, Hebrew University, Mount Scopus, Jerusalem, \\ Israel \\ ${ }^{3}$ CET-Center for Educational Technology, Tel-Aviv, Israel \\ ${ }^{4}$ The Edmond J. Safra Brain Research Center and the Learning Disabilities Department, University of Haifa, \\ Haifa, Israel \\ Email: baham@cet.ac.il
}

Received 17 February 2015; accepted 8 March 2015; published 11 March 2015

Copyright (c) 2015 by authors and Scientific Research Publishing Inc.

This work is licensed under the Creative Commons Attribution International License (CC BY). http://creativecommons.org/licenses/by/4.0/

(c) (i) Open Access

\section{Abstract}

The current study investigated the role of motivation in promoting reading comprehension skills among at-risk first graders. For this purpose, 20 at-risk first graders were recruited to participate in an interactive one-to-one tutoring reading comprehension intervention program. Following the children and tutors motivation level, four sub-groups were created: highly motivated children/ highly motivated tutors (HM-T/HM-L), highly motivated children/low motivated tutors (HM-L/ HM-T), low motivated children/highly motivated tutors (LM-L/HM-T) and low motivated children/ low motivated tutors (LM-L/LM-T). The children's progress in comprehension measures was documented. Across different time periods greater improvement was obtained among highly motivated children who were tutored by highly motivated tutor. The implications of the current findings were discussed.

\section{Keywords}

Motivation, Comprehension Skills, At-Linguistic Risk, Interactive Model, Computer Assisted, Intervention Program 


\section{Introduction}

Reading comprehension, as conveyed in our ability to construct meaning from print, is a core literacy skill, required for adaptive functioning in the $21^{\text {st }}$ century, especially such, it is not surprising to witness the extensive efforts and emphasis to promote reading comprehension skills, from early childhood. Along the years, grand scientific efforts have attempted to identify the core components of reading comprehension and the factors influencing its development (e.g.; Cain, Oakhill, \& Bryant, 2004; Hoover \& Gough, 1990; Verhoeven \& Van Leeuwe, 2008; Snow, 2002; Perfetti, Landi, \& Oakhill, 2005; Nation, Adams, Bowyer-Crane, \& Snowling, 1999).

One of the prominent reading comprehension models that obtained consistent scientific corroboration is the Simple View of Reading model (SVR) that outlines two core components of reading comprehension: decoding skills and language comprehension (Gough \& Tunmer, 1986; Hoover \& Gough, 1990). Indeed, the importance of skillful reading has been documented along the years (e.g. Perfetti, 1985; Adams, 1990; Stanovich, 1986, 1991; Snowling, 2000; Vellutino, Scanlon, \& Tanzman, 1994; Vellutino, Scanlon, \& Chen, 1995; Vellutino et al., 1996). As also proposed, oral language is essential for comprehension, where impairment in linguistic processing (e.g. morpho-syntactic, semantic processing and vocabulary knowledge) is seen to hinder reading comprehension, regardless of decoding skills (e.g. Cain, Oakhill, Barnes, \& Bryant, 2001; Nation, Clarke, Marshall, \& Durand, 2004; Nation \& Snowling, 1997; Yuill \& Oakhill, 1991).

However, the SVR model lacks the ability to conceptualize the complex and multi-componential essence of reading comprehension. Accordingly, higher-order and meta-cognitive skills, context, world knowledge, reading motivation and strategic reading are yet another important factors thought impact reading comprehension (e.g. Hannon \& Daneman, 2001; Pressley, 2000; Perfetti, Marron, \& Foltz, 1996; Graesser et al., 1994; Long \& Chong, 2001; Cain \& Oakhill, 2004; Perfetti, Landi, \& Oakhill, 2005; Snow, 2002). In addition to capacities and factors related to the reader, the RAND Reading Study Group (2002) outlines the role of the text in hand, the activity and their interaction with the reader, all subject to the socio-cultural context.

Due to the multifaceted nature of reading comprehension, the instructional and interventional designs are being continuously adapted to meet the vast growing scientific insights in the field, embracing comprehensive multi component approaches. In addition, individual differences between the capacities and needs of struggling readers (e.g. Snow, 2000; Torgesen, 2000; Catts, Hogan, \& Fey, 2003; Wise, Ring, \& Olson, 2000; Parrila, Aunola, Leskinen, Nurmi, \& Kirby, 2005) are also being considered, hence stressing the importance of differentiated literacy instruction (e.g. Foorman \& Torgesen, 2001; Denton, Vaughn, \& Fletcher, 2003; Reis et al., 2004; Tomlinson, 1999, 2003), enabled for example by one-to-one tutoring environments.

Motivation is a crucial component that insufficiently addressed yet in reading comprehension (e.g. Wigfield \& Guthrie, 2000), both essential in learning and teaching processes. Specifically, due to the complexity and demanding nature of reading comprehension, motivation is necessary for apt coping and acquisition of the required skills (Stipek, 2002). To a great extent, student's learning motivation is affected by teachers' classroom practices, such as their ability to foster student's motivation and sensitivity to the needs and interests of each student, especially among struggling reader. Cadima, Leal and Burchinak (2010) suggested that student-teacher interaction is important for academic success, adding up to previous findings regarding motivation as a mechanism for improving academic skills, especially among children who experienced repeated failures in reading.

Accordingly, the following section will review the benefices of one-to-one tutorial environments in promoting reading comprehension skills and the role of learning and teaching motivation.

\subsection{Individualized Literacy Instruction}

Reading intervention programs has extensively been embedded in one-to-one tutoring-based environments, yielding effective results in preventing and remediating reading difficulties (e.g. Clay, 1985; Wasik \& Salvin, 1993; Toregson, 2000; Hiebert \& Taylor, 2000; Elbaum, Vaughn, Hughes, \& Moody, 2000; D’Agostino \& Murphy, 2004; Juel, 1996).

One of the most prominent still implemented and effective one-to-one intervention reading tutoring modelsreading recovery — was developed and employed by Clay (1985), targeting struggling first graders. Thirty minutes daily intervention sessions were carried in a one-to-one tutoring environment, assigning for each student trained certified teacher. The students received, incorporating stories' reading activities and metacognitive reading comprehension strategies. The duration of the sessions depended on the progress of the students and whether 
they were successful in bridging the gaps with their class peers (approximately 12 - 30 weeks). The effectiveness of the program has been corroborated in different studies, indicating that the students participating in the program outperformed their peers in the control group, in all assessed measures (e.g. Askew \& Frasier, 1996; Askew, Kaye, Frasier, Mobasher, Anderson, \& Rodriguez, 2003; Deford, Pinnell, Lyons, \& Yong, 1988; Pinnell, Short, Leyons, \& Young, 1986; Pinnell, Lyons, DeFord, Bryek, \& Seltzer, 1994; Shanahan \& Barr, 1995).

Accordingly, one-to-one instruction is considered beneficial for struggling students, especially those who are at-risk for reading difficulties (Bloom, 1984; Jenkins, Mayhall, Peschka, \& Jenkins, 1974; Juel, 1991; Wasik \& Slavin, 1993) enabling extensive practice that is accustomed to the needs and capacities of each student. However, studies evaluating the efficacy of such environment, stress the importance of constructed program that is carried by trained certified teachers that have the required pedagogical knowledge and background in the field of reading acquisition (e.g. Houge, Geier, \& Peyton, 2008; Wasik \& Slavin, 1993).

\subsection{The Role of Motivation in Reading Instruction and Learning}

Motivation has been identified as a key factor for overall academic success and for reading performance in specific (e.g. Gotterfried, 1990; Baker \& Wigfield, 1999; Wigfield \& Guthrie, 2000; Gottfried, 1990; Guthrie et al., 2007; Wigfield, 2004; Taboada, Tonks, Wigfield, \& Guthrie, 2009; Chapman \& Tunmer, 1995; Guthrie, Wigfield, Metsala, \& Cox, 1999; Guthrie et al., 2006; Lepper, Henderlong, Corpus, \& Iyengar, 2005). In its’ broader definition, motivation is conceptualized as consistent selection of curtain action while designating the necessary resources to achieve the desired goal (Dornyei \& Ushioda, 2011).

Humans are bestowed with natural tendency for learning, steaming from their drive to explore the world and their surroundings. In general, motivation has long been linked to perceived efficacy, achievement expectancy, achievement goals and reward (e.g. Atkinson, 1964; Wigfield \& Eccles, 2000; Bandura, 1986; Schunk, 1991; Ames, 1984; Dweck, 1986; Maehr, 1984; Nicholls, 1984; Kaplan, Middleton, Urdan, \& Midgley, 2002). Hence, it is not surprising that one of the most prominent characteristics of struggling readers is their low motivation for reading — lack of initial drive-impacting their self-perception that ultimately hinder their enjoyment and valuation of self-initiated reading activities (e.g. Snow, Burns, \& Grin, 1998; Guthrie \& Davis, 2003). In addition, reading difficulties seem to influence student's social integration also experiencing lower cognitive abilities (See Wigfield \& Guthrie, 2000).

With regard to reading comprehension, Logan, Medford \& Hughes (2011), pointed to the predictive value of intrinsic motivation on the growth of reading comprehension competencies among struggling readers, thought to interact with the cognitive skills underlying reading comprehension (Taboada et al., 2009). The Results of the study indicated that among poor readers, motivational factors accounted for the variance in both decoding skills and reading comprehension and that intrinsic motivation affected the growth in the later, where greater improvement was noted across the scholastic year as a function of student's motivational level. Hence, enhancing motivation is crucial for reading.

Dornyei and Ushioda (2011) suggest that enhancing children's learning motivation can be achieved by:

1) Creating core motivational conditions, such as, positive student-teacher interaction (Cadima, Leal, \& Burchinak, 2010), supportive classroom environment (Rasinski \& Padak, 1996), encouraging small learning groups following the student's abilities, well organized class management and teacher's planning and construction of diverse and interesting lessons (Tyler, Taylor, Kane, \& Wooten, 2010; Emmer, Sabornie, Evertson, \& Weinstein, 2013; Emmer \& Stough, 2001).

2) Fostering initial motivation for learning (e.g. objective goal setting, encouragements and adaptation of learning material to the students' needs and interests).

3) Preserve and increase learning motivation and foster students' self-efficacy. The teacher is a key component in constructing motivating in-class environment and ensuring continues student's engagement in learning (Taylor, Harris, Pearson, \& Garcia, 1995; Davidson \& O’Leary, 1990; Mathewson, 1994).

Accordingly, motivation is an inseparable layer of reading comprehension skill and can be greatly impacted from instructional practices, including student-teacher interaction. Scientific evidence points to the contribution of positive student-teacher relationship for student's academic success, school adjustment and motivation (e.g. Meehan, Hughes, \& Cavell, 2003; Pianta, Steinberg, \& Rollins, 1995; Reeve, Bolt, \& Cai, 1999; Rigby, Deci, Patrick, \& Ryan, 1992; Vallerand et al., 1997). As such, the wellbeing and motivation of teachers' affects the classroom environment, including their relationship, expectancy and beliefs about their students. 


\subsection{The Current Study}

In line with the above mentioned the present study attempts to investigate the impact of the motivation on the efficacy of the process of instruction and learning comprehension skills among at-risk first graders.

Specifically, we attempt to investigate:

1) Is there an effect for the children's learning motivation on their progress in comprehension skills?

2) Is there an effect for the tutor's teaching motivation level on promoting comprehension skills?

3) Is there an interaction effect between the tutors' teaching motivation level and children's learning motivation, affecting the later progress in comprehension skills?

\section{Method}

\subsection{Participants}

Ultimately, 20 at-linguistic risk native Arabic speaking first graders, attending elementary school located in low SES neighborhood in northern Israel, were randomly assigned to participate in the intervention program that learned in the classroom, besides to the intervention program. For each child, a qualified tutor was assigned (third year college students seeking their teaching certificates). The children and the tutors were rated for their level of learning and teaching motivation, either by their teacher or by pedagogical supervisor in the college, respectively. As a result, four intervention sub-groups were created, each consisting of five pairs of tutors-tutees: highly motivated children/highly motivated tutors (HM-T/HM-L), highly motivated children/low motivated tutors (HM-L/HM-T), low motivated children/highly motivated tutors (LM-L/HM-T) and low motivated children/ low motivated tutors (LM-L/LM-T).

\subsection{The Intervention Procedure}

For the purpose of the current study, an interactive computer-assisted intervention program was designed. Following Adam's model of reading (1990), the program addressed four underlying mechanisms: phonology, orthography, semantics and context, seeking to promote decoding skills, fluency and reading comprehension among at-risk Arab first graders.

The instructional sessions were administered in one-to-one computer assisted tutoring environment to insure that the needs of each child are met. Prior to the program's commencement, the selected tutors underwent an extensive training, introducing the contents of the different sessions, activities, and guidelines on how to use the program software. Each tutor received a CD-ROM copy of the software, a guide with full instructions and recording booklet. Additionally, before and during the program, the tutors had weekly briefings, dealing with the difficulties arising during the sessions and the manners of dealing with them.

The program was composed of 26 instructional sessions. A 45-minute session was administrated during Arabic language lessons, two days a week during the scholastic years. In each week, one unit dealing with a presented narrative text was covered (an overall of 13 texts were presented), including pre-reading activates, while-reading and post-reading activities. At the beginning of the year, the texts were read to the children by their tutors since they were at the starting point of reading acquisition.

In each session, the tutor documented the child's responses and any incorporated modeling. In addition, the head researcher and a professional teacher held observational evaluation sessions, in order to ensure standardized and adequate delivery of the program.

\subsection{Measures}

To assess the progress in comprehension skills across different time points, data on each of the below-described measures were collected for each weekly unit:

1) Immediate story recall tasks: immediately after hearing a story read to them by the tutors, the children were required to recall the story that was narrated to them. The tutor documented the children's response.

2) Delayed story recall was assessed as a function of the children's capacity to recall a story that was narrated to them by the tutor in the previous session (i.e. on the second session of the same unit). The tutor documented the children's response.

3) Comprehension evaluation tasks that included a set of questions dealing with the presented texts in each unit, addressing the different components of reading comprehension skills as proposed by PIRLS (Progress in 
Reading Literacy Study) assessment framework (Mullis, Martin, Kennedy, Trong, \& Sainsbur, 2011). The questions incorporated explicit information retrieval, straightforward inference, interpretation, and integration of ideas.

On each measure, the children received a score ranging from one to four (1-very low performance, 2-basic, 3-intermediate, 4-proficient), based on different evaluation criteria (See Table 1). In order to follow the progress of the children throughout the intervention implementation, their performance on the different units' measures was evaluated at three time points:

- First measurement (M1) was held after the completion of the first six sessions (i.e. after dealing with the first three stories).

- Second measurement (M2) was held to evaluate the children competencies on the learned themes for stories six-eight (sessions 11 - 16).

- Third measurement (M3) was held at the end of the program implementation, addressing the learned stories 11 - 13 in sessions 21 - 26.

For each measurement, evaluating the children on three learned stories, an overall rating percentage was calculated for each of the assessed categories and comprehension indexes.

\subsection{Data Analysis}

To estimate the impact of the children learning motivation (First question) and tutor's teaching motivation (Second question) on the progress of the children in the intervention group Chi-squared tests were conducted, examining the prevalence of children in each performance level (very low performance, basic, intermediate and proficient). In addition, Mann-Whitney tests were performed in order to examine the difference in performance between highly motivated and low motivated children (First question) and to assess the progress of children when accompanied by tutors with high motivation level in comparison to when accompanied by tutors with low motivation (Second question).

To answer the third study question, Chi-squared test was calculated in order to compare the prevalence of the children in each performance level between the different intervention sub-groups (i.e. HM-T/HM-L, HM-T/ LM-L, LM-T/HM-L, LM-T/LM-L).

\section{Results}

\subsection{Improvement in Comprehension Skills in the Intervention Group as a Function of Learning Motivation Level}

Man-Whitney test was performed to assess the differences in comprehension skills as a function of the children's learning motivation: low motivation (LM-L) vs. high motivation (HM-L) across three points of time (See Figure 1).

Table 1. Scoring and evaluation criteria for the immediate story recall, delayed story tasks measures on the recall and reading comprehension different units (Makhoul, 2006).

\begin{tabular}{|c|c|c|c|c|}
\hline Evaluation criteria & $\begin{array}{c}1 \\
\text { very low performance }\end{array}$ & $\begin{array}{c}2 \\
\text { basic }\end{array}$ & $\begin{array}{c}3 \\
\text { intermediate }\end{array}$ & $\begin{array}{c}4 \\
\text { proficient }\end{array}$ \\
\hline \multicolumn{5}{|l|}{ Comprehension skills } \\
\hline $\begin{array}{l}\text { 1. } \quad \text { Explicit information retrieval. } \\
\text { 2. } \quad \text { Inference Making: } \\
\text { 2.1 Making straight forward inference; } \\
\text { 2.2 Interpretation and interpretation of } \\
\text { ideas. }\end{array}$ & $\begin{array}{l}\text { Incorrect answer/abstaining } \\
\text { from answering (after } \\
\text { verifying that the child has } \\
\text { fully understood the questions } \\
\text { and requirements). }\end{array}$ & $\begin{array}{l}\text { Partial concise } \\
\text { answer that } \\
\text { contains incorrect } \\
\text { details. }\end{array}$ & $\begin{array}{l}\text { Partial response } \\
\text { including only } \\
\text { correct details. }\end{array}$ & $\begin{array}{l}\text { Complete correct } \\
\text { answer. }\end{array}$ \\
\hline \multicolumn{5}{|l|}{ Immediate and delayed story recall } \\
\hline $\begin{array}{l}\text { 1. Recalling main details and events. } \\
\text { Usage of a story schema (background } \\
\text { details, characters, time and place, } \\
\text { conflict and solution) }\end{array}$ & $\begin{array}{l}\text { Incorrect recall of the story's } \\
\text { events or abstaining from } \\
\text { responding. }\end{array}$ & $\begin{array}{l}\text { Recalling words } \\
\text { appearing in the } \\
\text { text and incorrect } \\
\text { events' } \\
\text { sequencing. }\end{array}$ & $\begin{array}{l}\text { Partial recall of the } \\
\text { story events and } \\
\text { details while } \\
\text { maintaining a } \\
\text { partial sequencing } \\
\text { of events. }\end{array}$ & $\begin{array}{l}\text { Recalling main details } \\
\text { and events, ... } \\
\text { Usage of a story } \\
\text { schema and } \\
\text { maintaining logical and } \\
\text { adequate sequencing of } \\
\text { events. }\end{array}$ \\
\hline
\end{tabular}




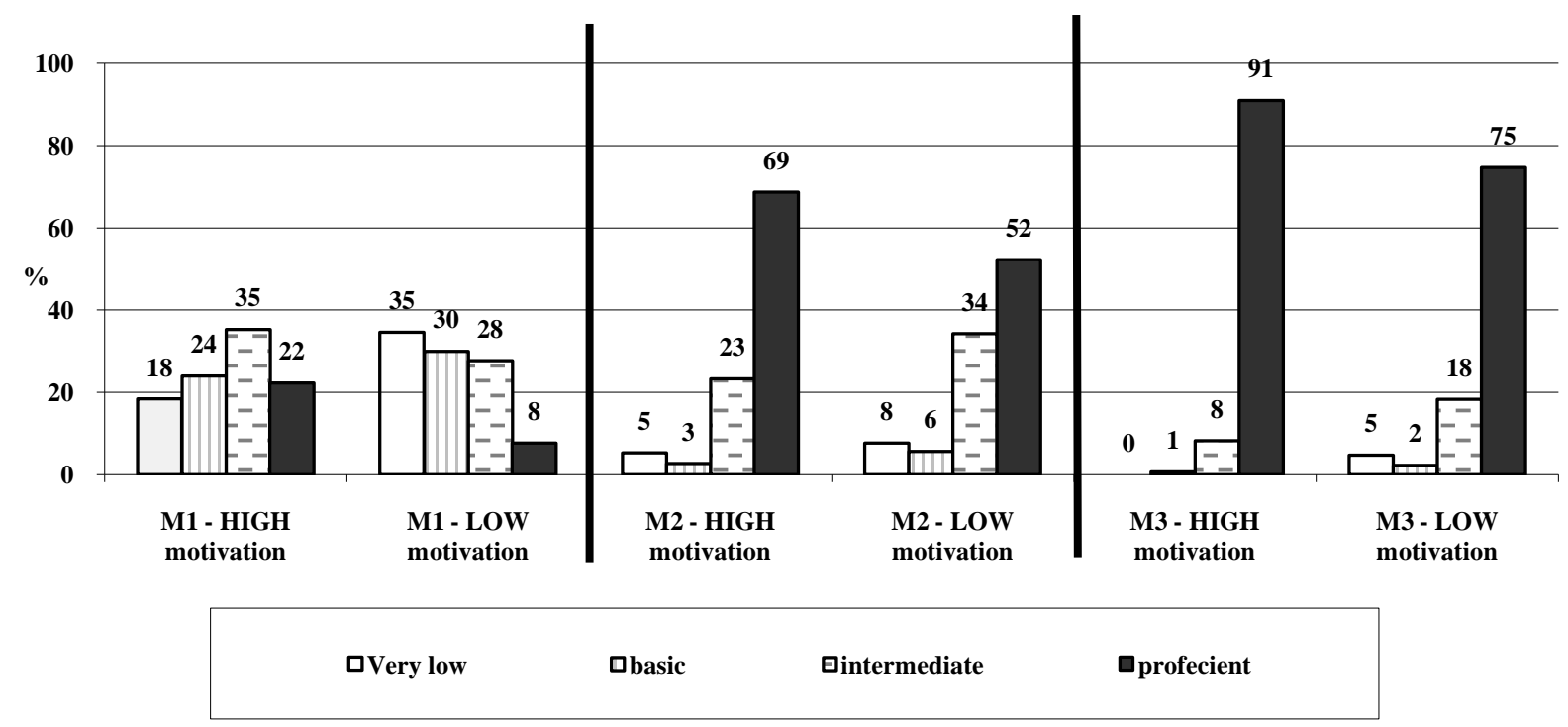

Figure 1. Achievement in comprehension skills as a function of the children motivation level in the three measurements (percentage).

Already in the first measurement, significantly higher performance is noted in the HM-L group when compared to LM-L group, where $22.3 \%$ of children in the HM-L demonstrated proficient performance level compared to only $7.7 \%$ in the LM-L group, $(Z=-2.6, p<.01)$. In addition, $35 \%$ of the children in the HM-L group were ranked as intermediate, compared to $28 \%$ in the LM-L group. Ultimately, the percentage of children in the HM-L group who demonstrated very low performance was lower in the HM-L group (18.4\%) when compared LM-L group (37.4\%).

In the second and the third measurement, no significant difference between HM-L group and LM-L group was encountered. However, the percentage of children depicting proficient performance level was higher in the HM-L group (68.7\% and 91\%, respectively) when compared to LM-L group (52\% and 74.7\%, respectively).

\subsection{Progress in the Intervention Group Comprehension Skills during the Program as a Function of the Tutors' Teaching Motivation}

Man-Whitney test was performed to assess the differences in comprehension skills as a function of the tutor's learning motivation: low motivation (LM-T) vs. high motivation (HM-T) across the three measurements.

In the first measurement, significantly higher percentage of children showed proficient level of performance in the HM-T group (21.7\%) when compared to LM-T group (8.3\%) $(Z=-2.26, p<.05)$. Furthermore, 35.7\% of the children in the LM-T had very low performance compared to only $17.3 \%$ in the HM-T group $(Z=-2.78, p$ $<.01)$.

In the second measurement, significantly higher performance was observed in the HM-T group $(Z=-3.03, p$ $<.01)$. The percentage of students ranked as proficient in the HM-T group $(78.7 \%)$ was higher compared to LM-T group (42.3\%). However, no significant difference was encountered between the two groups in the percentage of children who showed very low performance level (11.4\% in LM-T group and $1.7 \%$ in HM-T group).

In the last measurement, $97.3 \%$ of the children in HM-T group demonstrated proficient level of performance in comparison to $68.3 \%$ in the LM-T group, where significant difference was obtained $(Z=-3.30, p<.001)$ (See Figure 2).

\subsection{The Impact of Child-Tutor Motivation Level on Comprehension Skills}

In order to examine the interaction effect between the children's and tutors motivation on the children's progress in reading comprehension, four subgroups were created (See 2.1 in the Method Section): HM-T/HM-L, HM-T/ LM-L, LM-T/HM-L and LM-T/LM-L. Differences between the subgroup's performances were examined in each of the three carried measurements (See Table 2). 


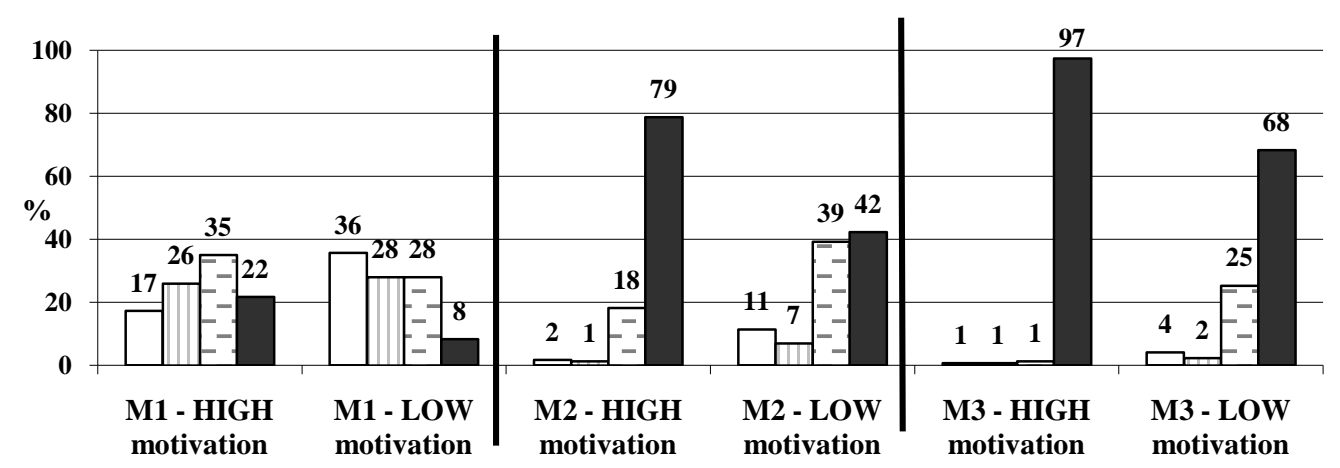

口Very low Performance $\square$ Baisc $\boxminus$ Intermediate $\square$ Profecient

Figure 2. Achievement in comprehension skills as a function of the tutor's motivation level in the three measurements (percentage).

Table 2. Achievement in comprehension performance as a function of the interaction effect between the tutors and children's motivation in the three measurements (percentage).

\begin{tabular}{|c|c|c|c|c|c|c|c|c|c|c|c|c|}
\hline \multirow{2}{*}{$\begin{array}{c}\text { Measurement } \\
\text { Group }\end{array}$} & \multicolumn{4}{|c|}{ First } & \multicolumn{4}{|c|}{ Second } & \multicolumn{4}{|c|}{ Third } \\
\hline & $\begin{array}{l}\text { HM-T } \\
\text { /HM-L }\end{array}$ & $\begin{array}{l}\text { LM-T } \\
/ \text { HM-L }\end{array}$ & $\begin{array}{l}\text { HM-T } \\
/ \text { LM-L }\end{array}$ & $\begin{array}{l}\text { LM-T } \\
\text { /LM-L }\end{array}$ & $\begin{array}{l}\text { HM-T } \\
\text { /HM-L }\end{array}$ & $\begin{array}{c}\text { LM-T } \\
/ \text { HM-L }\end{array}$ & $\begin{array}{l}\text { HM-T } \\
\text { /LM-L }\end{array}$ & $\begin{array}{l}\text { LM-T } \\
\text { /LM-L }\end{array}$ & $\begin{array}{l}\text { HM-T } \\
/ \text { HM-L }\end{array}$ & $\begin{array}{l}\text { LM-T } \\
\text { /HM-L }\end{array}$ & $\begin{array}{l}\text { HM-T } \\
\text { /LM-L }\end{array}$ & $\begin{array}{l}\text { LM-T } \\
\text { /LM-L }\end{array}$ \\
\hline Very low performance & 10.0 & 24.7 & 26.7 & 44.6 & 3.4 & .0 & 7.4 & 15.3 & .0 & 1.3 & .0 & 8.0 \\
\hline Basic & 22.7 & 29.3 & 25.3 & 30.7 & .0 & 2.7 & 5.3 & 8.7 & 1.3 & .0 & .0 & 4.7 \\
\hline Intermediate & 35.3 & 34.7 & 35.3 & 20.7 & 11.3 & 25.3 & 35.3 & 43.3 & 2.0 & 0.7 & 14.7 & 36.0 \\
\hline Proficient & 32.0 & 11.3 & 12.7 & 4.0 & 85.3 & 72.0 & 52.0 & 32.7 & 96.7 & 98.0 & 85.3 & 51.3 \\
\hline
\end{tabular}

In the first measurement, significantly higher percentage of children achieved the proficient level of performance in the HM-T/HM-L sub-group, when compared to HM-T/LM-L (11.3\%) and LM-T/HM-L (12.7\%), where the lowest percentage was encountered in the LM-T/LM-L subgroup (4\%).

When comparing the progress of the HM-T/LM-L and LM-T/HM-L progress in the second and last measurements, $72 \%$ and $98 \%$ of the children demonstrated proficient level of performance in the HM-T/LM-L group, respectively, as compared to only $52 \%$ and $85.3 \%$ in the LM-T/HM-L group, respectively. Ultimately, the results point to much smaller gains in comprehension skills in the LM-T/LM-L group, across the second (32.7\%) and last measurements (51.3\%).

\section{Discussion}

The present study attempted to examine the role of learning and instruction motivation on acquiring different comprehension skills among at-risk first graders, participating in balanced multi-componential Arabic reading comprehension intervention program. Specifically, we investigated the impact of learning motivation, teaching motivation as well as the reciprocal effect of teaching-learning motivation on the children's progress in reading comprehension skills. For this purpose, on each weekly unit, the students' performance was evaluated by utilizing different comprehension measures, including immediate, delayed story recall tasks, and reading comprehension activities. To follow the children's progress along the intervention program, measurements across three time points along the program were carried.

The results in the current study pointed to the impact of learning motivation on the children's progress in reading comprehension skills, thus pointing to its effect on the obtained gains in learning environments. Our findings points to greater gains in reading comprehension performance, following their participation in the intervention program when compared to the HM-L group, when compared to LM-L group. Indeed, accumulated recent scientific evidence emphasizes the role of motivation in reading comprehension processes and its development, where correlation was encountered between motivation level and growth in comprehension skills (e.g. 
Taboada et al., 2009; Guthrie et al., 1999; Guthrie et al., 2007; Anmarkrud \& Braten, 2009; Stipek, 2002; Gottfried, 1990; Hidi \& Harackiewicz, 2000; Wigfield \& Guthrie, 1997; Guthrie et al., 2007).

When examine the effect of the tutors' teaching motivation on the performance of the intervention group, the results indicate that the children accompanied by highly motivated tutors showed greater improvement, as reflected by higher percentage of children in the HM-T group, achieving proficient performance level in the last measurement when compared to the LM-T group. Little research has focused on investigating the direct impact of teachers motivation in learning environments, despite the encountered effect of teachers behavior in class on students motivation, achievements and learning gains (e.g. Reeve, Bolt, \& Cai, 1999; Rigby, Deci, Patrick, \& Ryan, 1992; Vallerand et al., 1997; Klem \& Connell, 2004). In specific, enhancing student's motivation relies greatly on instructional practices. For example, in their Concept-Oriented Reading Instruction (CORI) and Strategic Instruction (SI) models of reading instruction, Wigfield and Guthrie (2000) proposed several instructional approaches that are thought to improve reading performance and motivation, such as encouraging students' autonomy, goal-oriented instruction for reading, engaging in reading related social interactions, maintaining a supportive and good teacher-student relationship and providing stimulating activities.

As suggested above, the combined motivational level of the children and tutors seemed to affect the former progress in comprehension throughout the program. Across the three measurements, highly motivated children who were tutored by tutors with high teaching motivation seemed to benefit more from the program, arriving to higher attainments when compared to their peers in the other subgroups. However, marked progress was also noted among highly motivated children that were tutored by low motivated tutors. In contrast, the LM-T/LM-T subgroup showed the smallest improvement. In conclusion, the results imply the role of the teacher in advancing struggling readers and assisting them to fulfill their potentials.

With regard to the combined effect of tutor-student motivation level on children's comprehension growth, the results of the current study point to maximized gains in reading comprehension in the HM-L/HM-T group when compared to the HM-L/LM-T and LM-L/HM-T. Furthermore, the combination of LM-L and LM-T has resulted to be the least effective in promoting reading comprehension skills among struggling readers.

When relating to the proposed reading comprehension model by RAND study group (2002), children's learning motivation, especially, reading motivation impact reading comprehension. As being an inherent property of the reader, it affects the suggested dynamics operating between the former, the text and activity. Additionally, our results add another layer that ought to be considered in reading comprehension instruction, after controlling for the "text" and "activity" components. Teaching motivation is seen to affect the gains obtained in reading comprehension in instructional contexts that can be both associated with instruction quality and to the reciprocal nature of student-teacher motivation. Thus, it can posit that motivation in another component operating on the readers and affecting its capacity to derive meaning from print.

\section{Conclusion}

The present study attempts to investigate the impact of the motivation on the efficacy of the process of instruction and learning comprehension skills among at-risk first graders. The obtained results suggest that motivation optimizes learning processes, especially, when both partners, the teacher and the student, have higher motivation levels. Despite the initial difficulties in language skills and the complexity of Arabic language, the highest improvement was noted among the highly motivated students who were tutored by highly motivated tutors.

Adequate promotion of comprehension skills requires comprehensive interactive approach that incorporates a structured interactive individual instruction that addresses the role of the motivational component on learning, emphasizing both the teacher and students motivation. Ultimately, the small numbers of participants limited our ability to draw clear-cut conclusion, creating the necessity to further examine the obtained results, its pedagogical implications and contribution to the existing literature.

\section{Acknowledgements}

The intervention program described above was built in the Hebrew university of Jerusalem. We would like to thank the NCJW Research Institute for Innovation in Education (in the Hebrew university in Jerusalem) for its support along the way in the development, research and operation of the program. The program is approved by the Israeli Ministry of Education. 


\section{References}

Adams, M. J. (1990). Beginning to Read: Thinking and Learning about Print. Cambridge, MA: MIT Press.

Anmarkrud, Ø., \& Braten, I. (2009). Motivation for Reading Comprehension. Learningand Individual Differences, 19, 252256. http://dx.doi.org/10.1016/j.lindif.2008.09.002

Ames, C. (1984). Achievement Attributions and Self-Instructions under Competitive and Individualistic Goal Structures. Journal of Educational Psychology, 76, 478. http://dx.doi.org/10.1037/0022-0663.76.3.478

Askew, B. J., Kaye, E., Frasier, D. F., Fort Bend, I. S. D., Mobasher, M., Anderson, N., \& Rodríguez, Y. G. (2003). Making a Case for Prevention in Education. Literacy, 6, 43-73.

Askew, B. J., Wickstrom, C., \& Frasier, D. F. (1996). An Exploration of Literacy Behaviors of Children Following an Early Intervention Program. New York, NY: American Educational Research Association Conference.

Atkinson, J. W. (1964). An Introduction to Motivation. Princeton, NJ: Van Nostrand.

Baker, L., \& Wigfield, A. (1999). Dimensions of Children’s Motivation for Reading and Their Relations to Reading Activity and Reading Achievement. Reading Research Quarterly, 34, 452-477. http://dx.doi.org/10.1598/RRQ.34.4.4

Bandura, A. (1986). Social Foundations of Thought and Action: A Social Cognitive Theory. Englewood Cliffs, NJ: Prentice-Hall, Blackwell.

Bloom, B. S. (1984). The 2 Sigma Problem: The Search for Methods of Group Instruction as Effective as One-to-One Tutoring. Educational Researcher, 13, 4-16. http://dx.doi.org/10.3102/0013189X013006004

Cadima, J., Leal, T., \& Burchinal, M. (2010). The Quality of Teacher-Student Interactions: Associations with First Graders' Academic and Behavioral Outcomes. Journal of School Psychology, 48, 457-482. http://dx.doi.org/10.1016/j.jsp.2010.09.001

Cain, K., \& Oakhill, J. (2004). Reading Comprehension Difficulties. In Handbook of Children’s Literacy (pp. 313-338). Heidelberg: Springer. http://dx.doi.org/10.1007/978-94-017-1731-1_18

Cain, K., Oakhill, J., \& Bryant, P. (2004). Children’s Reading Comprehension Ability: Concurrent Prediction by Working Memory, Verbal Ability, and Component Skills. Journal of Educational Psychology, 96, 31-42. http://dx.doi.org/10.1037/0022-0663.96.1.31

Catts, H. W., Hogan, T. P., \& Fey, M. E. (2003). Subgrouping Poor Readers on the Basis of Individual Differences in Reading-Related Abilities. Journal of Learning Disabilities, 36, 151-164. http://dx.doi.org/10.1177/002221940303600208

Chapman, J. W., \& Tunmer, W. E. (1995). Development of Young Children’s Reading Self-Concepts: An Examination of Emerging Subcomponents and Their Relationship with Reading Achievement. Journal of Educational Psychology, 87, 154-167. http://dx.doi.org/10.1037/0022-0663.87.1.154

Clay, M. M. (1985). The Early Detection of Reading Difficulties (3rd ed.). Auckland: Heinemann.

D’Agostino, J. V., \& Murphy, J. A. (2004). A Meta-Analysis of Reading Recovery in United States Schools. Educational Evaluation and Policy Analysis, 26, 23-28. http://dx.doi.org/10.3102/01623737026001023

Davidson, N., \& O’Leary, P. W. (1990). How Cooperative Learning Can Enhance Mastery Teaching. Educational Leadership, 47, 30-33.

DeFord, D. E., Pinnell, G. S., Lyons, C. A., \& Young, P. (1988). Reading Recovery: Vol. IX, Report of the Follow-Up Studies. Columbus, $\mathrm{OH}$ : The Ohio State University.

Denton, C. A., Vaughn, S., \& Fletcher, J. M. (2003). Bringing Research-Based Practice in Reading Intervention to Scale. Learning Disabilities Research \& Practice, 18, 201-211. http://dx.doi.org/10.1111/1540-5826.00075

Dweck, C. S. (1986). Motivational Processes Affecting Learning. American Psychologist, 41, 1040-1048. http://dx.doi.org/10.1037/0003-066X.41.10.1040

Elbaum, B., Vaughn, S., Tejero Hughes, M., \& Watson Moody, S. (2000). How Effective Are One-to-One Tutoring Programs in Reading for Elementary Students at Risk for Reading Failure? A Meta-Analysis of the Intervention Research. Journal of Educational Psychology, 92, 605-619. http://dx.doi.org/10.1037/0022-0663.92.4.605

Emmer, E. T., \& Stough, L. M. (2001). Classroom Management: A Critical Part of Educational Psychology, with Implications for Teacher Education. Educational Psychologist, 36, 103-112. http://dx.doi.org/10.1207/S15326985EP3602_5

Emmer, E., Sabornie, E., Evertson, C. M., \& Weinstein, C. S. (Eds.) (2013). Handbook of Classroom Management: Research, Practice, and Contemporary Issues. London: Routledge.

Foorman, B. R., \& Torgesen, J. (2001). Critical Elements of Classroom and Small-Group Instruction Promote Reading Success in All Children. Learning Disabilities Research \& Practice, 16, 203-212.

http://dx.doi.org/10.1111/0938-8982.00020

Gottfried, A. E. (1990). Academic Intrinsic Motivation in Young Elementary School Children. Journal of Educational Psy- 
chology, 82, 525-538. http://dx.doi.org/10.1037/0022-0663.82.3.525

Gough, P. B., \& Tunmer, W. E. (1986). Decoding, Reading, and Reading Disability. Remedial and Special Education, 7, 610. http://dx.doi.org/10.1177/074193258600700104

Graesser, A. C., Singer, M., \& Trabasso, T. (1994). Constructing Inferences during Narrative Text Comprehension. Psychological Review, 101, 371-395. http://dx.doi.org/10.1037/0033-295X.101.3.371

Guthrie, J. T., Hoa, A. L. W., Wigfield, A., Tonks, S. M., Humenick, N. M., \& Littles, E. (2007). Reading Motivation and Reading Comprehension Growth in the Later Elementary Years. Contemporary Educational Psychology, 32, $282-313$. http://dx.doi.org/10.1016/j.cedpsych.2006.05.004

Guthrie, J. T., Wigfield, A., Humenick, N. M., Perencevich, K. C., Taboada, A., \& Barbosa, P. (2006). Influences of Stimulating Tasks on Reading Motivation and Comprehension. The Journal of Educational Research, 99, 232-246. http://dx.doi.org/10.3200/JOER.99.4.232-246

Guthrie, J. T., Wigfield, A., Metsala, J. L., \& Cox, K. E. (1999). Motivational and Cognitive Predictors of Text Comprehension and Reading Amount. Scientific Studies of Reading, 3, 231-256. http://dx.doi.org/10.1207/s1532799xssr0303_3

Hannon, B., \& Daneman, M. (2001). A New Tool for Measuring and Understanding Individual Differences in the Component Processes of Reading Comprehension. Journal of Educational Psychology, 93, 103-128.

http://dx.doi.org/10.1037/0022-0663.93.1.103

Hiebert, E. H., \& Pearson, P. D. (2000). Building on the Past, Bridging to the Future: A Research Agenda for the Center for the Improvement of Early Reading Achievement. The Journal of Educational Research, 93, 133-144. http://dx.doi.org/10.1080/00220670009598702

Hoover, W. A., \& Gough, P. B. (1990). The Simple View of Reading. Reading and Writing, 2, 127-160. http://dx.doi.org/10.1007/BF00401799

Houge, T. T., Geier, C., \& Peyton, D. (2008). Targeting Adolescents’ Literacy Skills Using One-to-One Instruction with Research-Based Practices. Journal of Adolescent \& Adult Literacy, 51, 640-650. http://dx.doi.org/10.1598/JAAL.51.8.3

Jenkins, J. R., Mayhall, W. F., Peschka, C. M., \& Jenkins, L. M. (1974). Comparing Small Group and Tutorial Instruction in Resource Rooms. Exceptional Children, 40, 245-250.

Juel, C. (1991). Cross-Age Tutoring between Student Athletes and At-Risk Children. The Reading Teacher, 45, $178-186$.

Juel, C. (1996). What Makes Literacy Tutoring Effective? Reading Research Quarterly, 31, 268-289. http://dx.doi.org/10.1598/RRQ.31.3.3

Kaplan, A., Middleton, M. J., Urdan, T., \& Midgley, C. (2002). Achievement Goals and Goal Structures. In C. Midgley (Ed.), Goals, Goal Structures, and Patterns of Adaptive Learning (pp. 21-53). Mahwah, NJ: Erlbaum.

Lepper, M. R., Corpus, J. H., \& Iyengar, S. S. (2005). Intrinsic and Extrinsic Motivational Orientations in the Classroom: Age Differences and Academic Correlates. Journal of Educational Psychology, 97, 184-196.

http://dx.doi.org/10.1037/0022-0663.97.2.184

Logan, S., Medford, E., \& Hughes, N. (2011). The Importance of Intrinsic Motivation for High and Low Ability Readers' Reading Comprehension Performance. Learning and Individual Differences, 21, 124-128. http://dx.doi.org/10.1016/j.lindif.2010.09.011

Long, D. L., \& Chong, J. L. (2001). Comprehension Skill and Global Coherence: A Paradoxical Picture of Poor Comprehenders’ Abilities. Journal of Experimental Psychology: Learning, Memory, and Cognition, 27, 1424-1429. http://dx.doi.org/10.1037/0278-7393.27.6.1424

Maehr, M. L. (1984). Meaning and Motivation: Toward a Theory of Personal Investment. Research on Motivation in Education, 1, 115-144.

Mathewson, G. C. (1994). Model of Attitude Influence upon Reading and Learning to Read. In R. B. Ruddell, \& H. Singer (Eds.), Theoretical Models and Processes of Reading (3rd ed., pp. 1131-1161). Newark, DE: International Reading Association.

Meehan, B. T., Hughes, J. N., \& Cavell, T. A. (2003). Teacher-Student Relationships as Compensatory Resources for Aggressive Children. Child Development, 74, 1145-1157. http://dx.doi.org/10.1111/1467-8624.00598

Nation, K., \& Snowling, M. (1997). Assessing Reading Difficulties: The Validity and Utility of Current Measures of Reading Skill. British Journal of Educational Psychology, 67, 359-370. http://dx.doi.org/10.1111/j.2044-8279.1997.tb01250.x

Nation, K., Clarke, P., Marshall, C. M., \& Durand, M. (2004). Hidden Language Impairments in Children Parallels between Poor Reading Comprehension and Specific Language Impairment. Journal of Speech, Language, and Hearing Research, 47, 199-211. http://dx.doi.org/10.1044/1092-4388(2004/017)

Nicholls, J. G. (1984). Achievement Motivation: Conceptions of Ability, Subjective Experience, Task Choice, and Performance. Psychological Review, 91, 328-346. http://dx.doi.org/10.1037/0033-295X.91.3.328 
Parrila, R., Aunola, K., Leskinen, E., Nurmi, J. E., \& Kirby, J. R. (2005). Development of Individual Differences in Reading: Results from Longitudinal Studies in English and Finnish. Journal of Educational Psychology, 97, 299-319. http://dx.doi.org/10.1037/0022-0663.97.3.299

Perfetti, C. A., Landi, N., \& Oakhill, J. (2005). The Acquisition of Reading Comprehension Skill. In M. J. Snowling, \& C. Hulme (Eds.), The Science of Reading: A Handbook (pp. 227-247). Oxford: Blackwell.

Perfetti, C. A., Marron, M. A., \& Foltz, P. W. (1996). Sources of Comprehension Failure: Theoretical Perspectives and Case Studies. In C. Cornoldi, \& J. V. Oakhill (Eds.), Reading Comprehension Difficulties: Processes and Remediation (pp. 137-165). Mahwah, NJ: Erlbaum.

Perfetti, C. A. (1985). Reading Ability. New York: Oxford University Press.

Pianta, R. C., Steinberg, M. S., \& Rollins, K. B. (1995). The First Two Years of School: Teacher-Child Relationships and Deflections in Children's Classroom Adjustment. Development and Psychopathology, 7, 295-312. http://dx.doi.org/10.1017/S0954579400006519

Pinnell, G. S., Lyons, C. A., Deford, D. E., Bryk, A. S., \& Seltzer, M. (1994). Comparing Instructional Models for the Literacy Education of High-Risk First Graders. Reading Research Quarterly, 29, 8-39.

Pinnell, G. S., Short, A. G., Lyons, C. A., \& Young, P. (1986). The Reading Recovery Project in Columbus, OH, Year I: 1985-1986. Columbus., OH: Ohio State University.

Pressley, M. (2000). What Should Comprehension Instruction Be the Instruction of? In: M. Kamil, P. Mosenthal, P. Pearson, \& R. Barr (Eds.), Handbook of Reading Research (Vol. III, pp. 545-561). Mahwah, NJ: Lawrence Erlbaum.

RAND Reading Study Group (2002). Reading for Understanding: Toward an R\&D Program in Reading Comprehension. Santa Monica, CA: RAND.

Rasinski, T., \& Padak, N. (1996). Holistic Reading Strategies: Teaching Children Who Find Reading Difficult. Des Moines, IA: Prentice-Hall, Inc.

Reeve, J., Bolt, E., \& Cai, Y. (1999). Autonomy-Supportive Teachers: How They Teach and Motivate Students. Journal of Educational Psychology, 91, 537-548. http://dx.doi.org/10.1037/0022-0663.91.3.537

Reis, S. M., Gubbins, E. J., Briggs, C. J., Schreiber, F. J., Richards, S., Jacobs, J. K., Eckert, R. D., \& Renzulli, J. S. (2004). Reading Instruction for Talented Readers: Case Studies Documenting Few Opportunities for Continuous Progress. Gifted Child Quarterly, 48, 315-338. http://dx.doi.org/10.1177/001698620404800406

Rigby, C. S., Deci, E. L., Patrick, B. C., \& Ryan, R. M. (1992). Beyond the Intrinsic-Extrinsic Dichotomy: Self-Determination in Motivation and Learning. Motivation and Emotion, 16, 165-185. http://dx.doi.org/10.1007/BF00991650

Schunk, D. H. (1991). Self-Efficacy and Academic Motivation. Educational Psychologist, 26, 207-231. http://dx.doi.org/10.1080/00461520.1991.9653133

Shanahan, T., \& Barr, R. (1995). Reading Recovery: An Independent Evaluation of the Effects of an Early Instructional Intervention for At-Risk Learners. Reading Research Quarterly, 30, 958-996. http://dx.doi.org/10.2307/748206

Snow, C. (2002). Reading for Understanding: Toward an R\&D Program in Reading Comprehension. Santa Monica, CA: RAND.

Snow, C. E., Burns, M. S., \& Griffin, P. (Eds.) (1998). Preventing Reading Difficulties in Young Children. Washington DC: National Academy Press.

Snowling, M. J. (2000). Dyslexia. Oxford: Blackwell.

Stanovich, K. E. (1991). Word Recognition: Changing Perspectives. In R. Barr, M. L. Kamil, P. Mosenthal, \& P. D. Pearson (Eds.), Handbook of Reading Research (Volume 2, pp. 418-452). New York: Longman.

Stanovich, K. E. (1986). Matthew Effects in Reading: Some Consequences of Individual Differences in the Acquisition of Literacy. Reading Research Quarterly, 21, 360-407. http://dx.doi.org/10.1598/RRQ.21.4.1

Stipek, D. J. (2002). Motivation to Learn: Integrating Theory and Practice. Boston, MA: Allyn \& Bacon.

Taboada, A., Tonks, S. M., Wigfield, A., \& Guthrie, J. T. (2009). Effects of Motivational and Cognitive Variables on Reading Comprehension. Reading and Writing, 22, 85-106. http://dx.doi.org/10.1007/s11145-008-9133-y

Taylor, B., Harris, L. A., Pearson, P. D., \& Garcia, G. (1995). Reading Difficulties: Instruction and Assessment (2nd ed.). New York: McGraw-Hill.

Torgesen, J. K. (2000). Individual Differences in Response to Early Interventions in Reading: The Lingering Problem of Treatment Resisters. Learning Disabilities Research \& Practice, 15, 55-64. http://dx.doi.org/10.1207/SLDRP1501_6

Tyler, J. H., Taylor, E. S., Kane, T. J., \& Wooten, A. L. (2010). Using Student Performance Data to Identify Effective Classroom Practices. The American Economic Review, 100, 256-260. http://dx.doi.org/10.1257/aer.100.2.256

Vallerand, R. J., Fortier, M. S., \& Guay, F. (1997). Self-Determination and Persistence in a Real-Life Setting: Toward a Mo- 
tivational Model of High School Dropout. Journal of Personality and Social psychology, 72, 1161-1176. http://dx.doi.org/10.1037/0022-3514.72.5.1161

Vellutino, F. R., Scanlon, D. M., \& Tanzman, M. S. (1994). Components of Reading Ability: Issues and Problems in Operationalizing Word Identification, Phonological Coding, and Orthographic Coding. In G. R. Lyon (Ed.), Frames of Reference for the Assessment of Learning Disabilities: New Views on Measurement Issues (pp. 279-324). Baltimore, MD: Paul H. Brookes.

Wasik, B. A., \& Slavin, R. E. (1993). Preventing Early Reading Failure with One-to-One Tutoring: A Review of Five Programs. Reading Research Quarterly, 28, 179-200.

Wigfield, A., \& Eccles, J. S. (2000). Expectancy-Value Theory of Achievement Motivation. Contemporary Educational Psychology, 25, 68-81. http://dx.doi.org/10.1006/ceps.1999.1015

Wigfield, A., \& Guthrie, J. T. (2000). Engagement and Motivation in Reading. Handbook of Reading Research, 3, 403-422.

Wise, B. W., Ring, J., \& Olson, R. K. (2000). Individual Differences in Gains from Computer-Assisted Remedial Reading. Journal of Experimental Child Psychology, 77, 197-235. http://dx.doi.org/10.1006/jecp.1999.2559

Yuill, N., \& Oakhill, J. (1991). Children's Problems in Text Comprehension: An Experimental Investigation. Cambridge: Cambridge University Press. 